\title{
HUBUNGAN TINGKAT PENDIDIKAN DAN DUKUNGAN KELUARGA TERHADAP KECEMASAN PASIEN PRA OPERASI DI RSUD PANGKEP
}

\author{
KISTAN \\ AKPER Batari Toja Watampone \\ Alamat korespondensi : (Kistan@bataritoja.ac.id/082280444885)
}

\begin{abstract}
ABSTRAK
Kecemasan merupakan respon emosional yang dapat terjadi pada pasien pra operasi. Tujuan penelitian ini adalah untuk mengetahui hubungan tingkat pendidikan dan dukungan keluarga terhadap Kecemasan pada pasien pra operasi di RSUD Pangkep. Penelitian ini merupakan jenis penelitian Korelasi dengan pendekatan cross-sectional. populasi dalam penelitian ini adalah pasien pra operasi di RSUD Pangkep. Pengambilan sampel menggunakan tehnik non probability sampling dengan jenis consecutive sampling, didapatkan 52 responden. Uji statistik menggunakan analisis bivariat dengan uji chi-square dengan nilai $\alpha=0.05$ diperoleh hasil perhitungan dengan nilai $\rho$ value 0.04 artinya ada hubungan antara tingkat pendidikan dengan kecemasan pasien pra operasi dan nilai $\rho$ value 0.005 artinya ada hubungan antara dukungan keluarga terhadap kecemasan pasien pra operasi di RSUD Pangkep. Dimana dukungan keluarga mempunyai hubungan yang dominan terhadap kecemasan pasien pra operasi. Diharapkan kepada keluarga dapat memberikan dukungan kepada pasien pra operasi agar lebih termotivasi dan percaya diri pada proses operasi sehingga dapat membantu kelancaran proses operasi yang akan dilakukan.
\end{abstract}

\section{Kata Kunci: Tingkat Pendidikan, Dukungan Keluarga, Kecemasan}

\section{PENDAHULUAN}

Kecemasan atau Anseitas merupakan istilah yang sangat akrab dengan kehidupan sehari-hari yang menggambarkan keadaan khawatir, gelisah, takut, tidak tentram di sertai berbagai keluhan fisik (Dalami Dkk, 2009).

Kecemasan juga bisa di alami oleh seseorang yang harus menjalani tindakan medis yaitu operasi dan berperan sebagai pasien. Maka tak heran jika sering kali pasien dan keluarganya menunjukkan sikap yang agak berlebihan dengan kecemasan yang mereka alami. Menurut Yeremi (2012), salah satu peneliti menyebutkan bahwa $80 \%$ dari pasien yang akan menjalani pembedahan mengalami kecemasan (Ferlina, 2002). Carpenito, juga mengatakan bahwa $90 \%$ pasien pra operasi berpotensi mengalami kecemasan (Bahsoan, 2013).

Pra operasi merupakan kondisi yang dimulai ketika keputusan untuk intervensi bedah dibuat dan berakhir ketika pasien dikirim ke kamar operasi, proses perawatan di rumah sakit seringkali mengabaikan aspekaspek psikologis, sehingga menimbulkan berbagai permasalahan psikologis bagi pasien yang salah satunya kecemasan. Kecemasan yang dialami biasanya terkait dengan prosedur asing dan juga ancaman terhadap keselamatan jiwa akibat segala macam prosedur pembedahan dan tindakan pembiusan. Hasil penelitian menunjukkan bahwa dari sampel yang diteliti menunjukkan ada hubungan yang signifikan antara tingkat pendidikan dengan tingkat kecemasan yang diperoleh (Kuraesin, 2009).

Menurut penelitian yang dilakukan oleh P.Rini (2012) beberapa pasien yang mengalami kecemasan berat terpaksa menunda jadwal operasi, sehingga perlu mekanisme koping yang dapat membantu pasien dalam menghadapi masalah ketakutan dan kecemasan ini, seperti berdoa, adanya orang terdekat, tingkat perkembangan pasien dan faktor pendukung seperti usia yang dewasa, pendidikan yang baik yang berhubungan dengan pengetahuan tentang penyakitnya, dan status ekonomi (Bahsoan, 2013).

Menurut data yang diperoleh RSUD Pangkep, Jumlah pasien operasi pada tahun 2013 dengan jumlah pasien 1383 pasien, yang terdiri dari jenis operasi khusus 148 pasien, jenis operasi besar 871 pasien, jenis operasi sedang, 364 pasien dan pada pasien jenis operasi kecil tidak terdapat pasien. Perkiraan untuk tahun 2014 ini pasien menjalani bedah akan sangat meningkat karena dari data yang di ambil hasil wawancara salah satu mahasiswa yang praktek di RSUD pangkep menyebutkan bahwa ada sekitar 6 orang pasien operasi setiap hari, mulai hari senin- 
jumat di bulan April - Mei. Sehingga peneliti dapat menyimpulkan pasien pra operasi satu minggu kedepan berkisar antara 30 pasien operasi, dan sekitar 120 pasien operasi tiap bulannya (Medical Record)

\section{BAHAN DAN METODE}

Lokasi, Populasi, Sampel

Penelitian ini dilaksanakan di RSUD Pangkep pada tanggal 13 Juni s/d 12 Juli 2014. Populasi pada penelitian ini adalah pasien pra operasi di RSUD Pangkep. Sampel pada penelitian ini adalah sampel yang masuk dalam kriteria Inklusi dan Eksklusi diperoleh sebanyak 52 sampel.

1. kriteria inklusi:

a. Bersedia menjadi responden

b. Dapat berkomunikasi dengan baik

c. Pasien yang terdaftar operasi di RSUD Pangkep

2. kriteria eksklusi:

a. Tidak bersedia menjadi responden

b. Tidak mampu berkomunikasi dengan baik atau tidak sadar

\section{Pengumpulan Data}

1. Data sekunder adalah data yang diperoleh dalam bentuk jadi dan telah diolah oleh pihak lain yang biasanya dalam bentuk publikasi.

2. Data primer adalah data yang dikumpulkan dan diolah sendiri oleh suatu organisasi atau perorangan langsung dari objeknya (Saryono 2014).

\section{Pengolahan Data}

\section{Editing}

Editing adalah tahapan kegiatan memeriksa validitas data yang masuk seperti memeriksa kelengkapan pengisian kuesioner, kejelasan jawaban, relevansi jawaban dan keseragaman suatu pengukuran.

2. Coding

Coding adalah tahapan kegiatan mengklasifikasi data dan jawaban menurut kategori masing-masing sehingga memudahkan dalam pengelompokan data.

3. Processing

Processing adalah tahapan kegiatan memproses data agar dapat dianalisis. Pemrosesan data dilakukan dengan cara memasukkan data hasil pengisian kuesioner ke dalam master tabel. (Hidayat, 2013).

\section{Analisis Data}

1. Analisis Univariat

Digunakan untuk mendeskripsikan variabel penelitian guna memperoleh gambaran atau karakteristik sebelum dilakukan analisi bivariat. Hasil dari penelitian ditampilkan dalam bentuk distribusi frekuensi.

2. Analisis Bivariat

Analisis bivariat yang dilakukan adalah tabulasi silang antara dua variabel yaitu variabel independen dan dependen. Analisis bivariat yang digunakan untuk mengetahui hubungan terhadap objek penelitian adalah menggunakan uji chi square.

\section{HASIL PENELITIAN}

1. Analisis Univariat

Tabel 1 Distribusi karakteristik responden Di Balai Besar Kesehatan Paru Masyarakat 2017. $(n=83)$

\begin{tabular}{|c|c|c|}
\hline Karakteristik & $\mathrm{n}$ & $\%$ \\
\hline Usia & & \\
16-20 tahun & 6 & 14,4 \\
$21-30$ tahun & 15 & 32,6 \\
$31-40$ tahun & 16 & 39,6 \\
$41-55$ tahun & 5 & 13,4 \\
\hline Jenis kelamin & & \\
Laki-Laki & 14 & 26,9 \\
Perempuan & 38 & 73,1 \\
\hline Suku & & \\
Makassar & 33 & 63,5 \\
Bugis & 19 & 36,5 \\
Lainnya & & \\
\hline
\end{tabular}

Dari tabel 1 menunjukkan dari 52 responden lebih banyak responden yang berada pada rentang usia 31-40 tahun, yaitu sebanyak 16 orang $(39,6 \%)$, dan paling sedikit responden berusia 41-55 tahun yaitu sebanyak 5 Responden $(13,4 \%)$. Berdasarkan jenis kelamin yang paling banyak adalah berjenis kelamin perempuan, yaitu dengan jumlah 38 responden $(73,1 \%)$, dan jenis kelamin lakilaki yaitu berjumlah 14 responden $(26,9 \%)$. Berdasarkan suku Responden paling banyak berasal dari suku Makassar yang berjumlah 33 orang $(63,5 \%)$, responden yang berasal dari suku bugis berjumlah 19 (36,5\%) Responden

2. Analisis Bivariat

Tabel 2 Hubungan antara tingkat pendidikan terhadap tingkat kecemasan pasien pra operasi di RSUD Pangkep 2014

\begin{tabular}{|c|c|c|c|c|c|c|}
\hline \multirow{2}{*}{ Kecemasan } & \multicolumn{3}{|c|}{ Tingkat Pendidikan } & \multicolumn{2}{|c|}{ Total } \\
\cline { 2 - 6 } & \multicolumn{2}{|c|}{ rendah } & \multicolumn{2}{|c|}{ Tinggi } & \\
\cline { 2 - 6 } & $\mathrm{n}$ & $\%$ & $\mathrm{n}$ & $\%$ & $\mathrm{n}$ & $\%$ \\
\hline Ringan & 5 & 9,6 & 2 & 3,8 & 7 & 13,5 \\
\hline Sedang & 35 & 67,3 & 2 & 3,8 & 37 & 71,2 \\
\hline Berat & 4 & 7,7 & 4 & 7,7 & 8 & 15,4 \\
\hline Total & 44 & 84,6 & 8 & 15,4 & 52 & 100 \\
\hline \multicolumn{7}{|c|}{$p=0,04$} \\
\hline
\end{tabular}


Berdasarkan tabel 2, diketahui dari jumlah 52 responden lebih banyak responden dengan tingkat kecemasan sedang yaitu sebanyak 35 orang $(67,3 \%)$ $9,6 \%)$. Sedangkan dari jumlah 8 responden $(15,4 \%)$ dengan tingkat kecemasan berat yaitu sebanyak 4 orang $(7,7 \%)$ yang memiliki pendidikan tinggi dan 4 orang $(7,7 \%)$ yang memiliki tingkat pendidikan rendah.

Setelah dilakukan analisis menggunakan uji Chi Square, diperoleh pvalue sebesar $0.04<\alpha 0.05$, dengan demikian dalam penelitian ini diterima, dan dapat dinyatakan ada hubungan antara tingkat pendidikan dan dukungan keluarga terhadap kecemasan pasien pra operasi di RSUD Pangkep.

Tabel 3 Hubungan antara dukungan keluarga terhadap tingkat kecemasan pasien pra operasi di RSUD Pangkep 2014

\begin{tabular}{|c|c|c|c|c|c|c|}
\hline \multirow{2}{*}{$\begin{array}{c}\text { Kecemasa } \\
\mathrm{n}\end{array}$} & \multicolumn{4}{|c|}{ Dukungan keluarga } & \multirow{2}{*}{ Total } \\
\cline { 2 - 6 } & \multicolumn{2}{|c|}{ Kurang } & \multicolumn{2}{|c|}{ Baik } & \multicolumn{1}{c|}{} \\
\cline { 2 - 6 } & $\mathrm{n}$ & $\%$ & $\mathrm{n}$ & $\%$ & $\mathrm{n}$ & $\%$ \\
\hline Ringan & 2 & 3,8 & 5 & 9,6 & 7 & 13,5 \\
\hline Sedang & 29 & 55,8 & 8 & 15,4 & 37 & 71,2 \\
\hline Berat & 8 & 15,4 & 0 & 0 & 8 & 15,4 \\
\hline Total & 39 & 75 & 13 & 25 & 52 & 100 \\
\hline \multicolumn{6}{|c|}{$p=0,005$} \\
\hline
\end{tabular}

Berdasarkan tabel 3, diketahui dari jumlah 7 responden $(13,5 \%)$ lebih banyak responden dengan dukungan keluarga yang baik tingkat kecemasan ringan yaitu sebanyak 5 orang $(9,6 \%)$ dari pada dukungan keluarga yang kurang yaitu 2 orang $(16,1 \%)$. Sedangkan dari jumlah 37 responden $(71,2 \%)$ dengan tingkat kecemasan sedang lebih banyak yang dukungan keluarga yang kurang yaitu sebanyak 29 orang $(55,8 \%)$ dari pada yang dukungan keluarganya baik yaitu 8 orang $(15,4 \%)$.

Setelah dilakukan analisis menggunakan uji Chi Square, diperoleh pvalue sebesar $0.005<a 0.05$, dengan demikian dalam penelitian ini diterima, dan dapat dinyatakan ada hubungan antara dukungan keluarga terhadap tingkat kecemasan pasien pra operasi di RSUD Pangkep 2014

\section{PEMBAHASAN}

1. Hubungan tingkat pendidikan dan terhadap kecemasan pasien pra operasi di RSUD Pangkep

Berdasarkan hasil penelitian yang dilakukan, maka diketahui dari jumlah 52 responden lebih banyak responden dengan tingkat kecemasan sedang yaitu sebanyak 35 orang $(67,3 \%) \quad 9,6 \%)$. Sedangkan dari jumlah 8 responden $(15,4 \%)$ dengan tingkat kecemasan berat yaitu sebanyak 4 orang $(7,7 \%)$ yang memiliki pendidikan tinggi dan 4 orang $(7,7 \%)$ yang memiliki tingkat pendidikan rendah.

Setelah dilakukan uji Chi Square, didapatkan nilai pvalue sebesar 0.023 , yang berarti $p$ value $0.04<\alpha 0.05$, dapat disimpulkan bahwa tingkat pendidikan mempunyai hubungan yang signifikan dengan tingkat kecemasan pasien pra operasi di RSUD Pangkep

Hasil penelitian ini sejalan dengan penelitian yang dilakukan oleh Kuraesin (2009), yang mana dalam penelitian tersebut menyimpulkan bahwa salah satu faktor yang berhubungan dengan tingkat kecemasan pasien pra operasi di RSUP Fatmawati adalah tingkat pendidikan Pendidikan merupakan proses perubahan sikap dan tingkah laku seseorang dalam usaha mendewasakan diri melalui upaya pengajaran dan latihan.

Berdasarkan teori yang telah dikemukakan diatas dan hasil penelitian, maka peneliti berpendapat dimana sesuai hasil penelitian ini bahwa ada hubungan antara tingkat pendidikan dengan tingkat kecemasan pasien pra operasi dimana dapat diartikan bahwa responden yang berpendidikan tinggi lebih mampu menggunakan pemahaman mereka dalam merespon kecemasan yang terjadi dalam dirinya.

2. Hubungan Dukungan Keluarga dengan Tingkat Kecemasan Pasien Pra Operasi di RSUD PAngkep

Berdasarkan hasil penelitian yang dilakukan, maka diketahui diketahui dari jumlah 7 responden $(13,5 \%)$ lebih banyak responden dengan dukungan keluarga yang baik tingkat kecemasan ringan yaitu sebanyak 5 orang $(9,6 \%)$ dari pada dukungan keluarga yang kurang yaitu 2 orang $(16,1 \%)$. Sedangkan dari jumlah 37 responden $(71,2 \%)$ dengan tingkat kecemasan sedang lebih banyak yang dukungan keluarga yang kurang yaitu sebanyak 29 orang $(55,8 \%)$ dari pada yang dukungan keluarganya baik yaitu 8 orang $(15,4 \%)$.

Setelah dilakukan uji Chi Square, didapatkan nilai pvalue sebesar 0.005 , yang berarti $p$ value $0.005<\alpha 0.05$, dapat disimpulkan bahwa dukungan keluarga mempunyai hubungan yang signifikan dengan tingkat kecemasan pasien pra operasi di RSUD Pangkep. 
Hasil penelitian ini sejalan dengan penelitian Nadeak (2010), yang menunjukkan bahwa adanya hubungan antara dukungan keluarga dengan tingkat kecemasan. Nilai positif pada koefisien korelasi menunjukkan bahwa semakin positif dukungan keluarga, maka semakin berkurang tingkat kecemasan seseorang sebaliknya, semakin negatif persepsi dukungan keluarga sebagai tinggi tingkat kecemasan seseorang

Menurut Friedman mengatakan bahwa fungsi keluarga merupakan sumber energi yang menentukan kebahagiaan keluarga yang saling mendukung, rasa dimiliki dan memiliki, rasa berarti serta sumber kasih sayang yang dapat menguatkan satu sama lain (Padilla, 2011).

Berdasarkan teori yang telah dikemukakan diatas dan hasil penelitian, maka peneliti berpendapat dimana sesuai hasil penelitian ini bahwa ada hubungan antara Dukungan keluarga dengan tingkat kecemasan pasien pra operasi diaman dapat diartikan bahwa semakin baik dukungan keluarga terhadap pasien pra operasi maka semakin menurun tingkat kecemasan pasien tersebut.

\section{KESIMPULAN}

1. Ada Hubungan antara Tingkat pendidikan terhadap kecemasan pasien pra operasi di RSUD Pangkep

2. Ada Hubungan antara dukungan keluarga terhadap kecemasan pasien pra operasi di RSUD Pangkep

\section{SARAN}

1. Bagi keluarga, kiranya berperan aktif dalam memberikan dukungan dan motivasi agar pasien bisa menyelesaikan operasinya dengan rileks.

2. Diharapkan adanya upaya untuk meningkatkan peran keluarga dan peran perawat dalam mengontrol dan memberikan edukasi sebelum operasi.

3. Bagi peneliti selanjutnya, diharapkan kepada peneliti selanjutnya dapat meneliti lebih dalam dan lebih jauh lagi serta menggunakan analisis yang berbeda dan metode yang berbeda sehingga memperkaya analisis data penelitian serta penelitian ini dapat menjadi bahan dasar dalam penelitian selanjutnya dan menambahkan variabel independen lainnya yang berpengaruh terhadap tingkat kecemasan

\section{DAFTAR PUSTAKA}

Bahsoan, 2013. Hubungan mekanisme koping dengan kecemasan pasien pra operasi di Ruang perawatan bedah RSUD Prof.DR.HI.Aloei Saboe Kota Gorontalo. Jurnal Kesehatan dan Olahraga. Volume 12. No 1: 244-249

Dalami, Dkk, 2009. Asuhan Keperawatan jiwa dengan masalah Psikososial. CVTrans Info Medika: Jakarta

Hidayat. 2013. Metode Penelitian Keperawatan dan Teknik Analisa Data. Jakarta: Salemba Medika

Kuraesin, D. (2009). Faktor-faktor yang Berhubungan Dengan Tingkat Kecemasan Pasien yang akan menjalani Operasi Mayor Elektif di Ruang Rawat Bedah RSUP Fatmawati Jakarta Selatan. Jurnal Ilmiah Kesehatan UIN. Volume 3. No 3: 89-95.

Nadeak, 2010. Fakultas IImu Keperawatan. USU. Hubungan Dukungan Keluarga dan Tingkat kecemasan pasien Pre Operasi di Ruangan RB RSUP HAM Medan. Jurnal Repository USU. Volume 12. No 7: 213-219

RSUD Pangkep. 2014. Pengambilan Data Awal. Makassar

Padila. 2012. Buku Ajar: Keperawatan Keluarga. Nuha Medika: Yogyakarta 